\title{
Anticancer activity of extracts derived from the mature roots of Scutellaria baicalensis on human malignant brain tumor cells Adrienne C Scheck ${ }^{1,2}$, Krya Perry ${ }^{1,3}$, Nicole C Hank ${ }^{1}$ and W Dennis Clark*3
}

\author{
Address: ${ }^{1}$ Neuro-Oncology Research, Barrow Neurological Institute ${ }^{\circledR}$ of St. Joseph's Hospital and Medical Center, Phoenix, AZ 85013, USA, \\ ${ }^{2}$ Neurosurgery Research, Barrow Neurological Institute ${ }^{\circledR}$ of St. Joseph's Hospital and Medical Center, Phoenix, AZ 85013, USA and ${ }^{3}$ School of Life \\ Sciences, Arizona State University, Tempe, AZ 85287-4501, USA
}

Email: Adrienne C Scheck - adrienne.scheck@chw.edu; Krya Perry - Krya.Perry@sccmail.maricopa.edu; Nicole C Hank - nicole.hank@chw.edu; W Dennis Clark* - wdclark@usbotanicals.net

* Corresponding author

Published: 16 August 2006

BMC Complementary and Alternative Medicine 2006, 6:27 doi:10.1 186/1472-6882-6-27

This article is available from: http://www.biomedcentral.com/l472-6882/6/27

(c) 2006 Scheck et al; licensee BioMed Central Ltd.

This is an Open Access article distributed under the terms of the Creative Commons Attribution License (http://creativecommons.org/licenses/by/2.0), which permits unrestricted use, distribution, and reproduction in any medium, provided the original work is properly cited.
Received: 27 February 2006

Accepted: 16 August 2006

\begin{abstract}
Background: Flavonoid-rich extracts from the mature roots of Scutellaria baicalensis have been shown to exhibit antiproliferative effects on various cancer cell lines. We assessed the ability of an ethanolic extract of $S$. baicalensis root to inhibit the proliferation of malignant glioma cells.

Methods: Cell lines derived from primary and recurrent brain tumors from the same patient and cells selected for resistance to the chemotherapeutic agent I,3-bis(2-chloroethyl)-I-nitrosourea $(B C N U)$ were used to identify antiproliferative effects of this extract when used alone and in conjunction with BCNU.

Results and discussion: Results indicated that Scutellaria baicalensis not only inhibits cellular growth in recurrent and drug resistant brain tumor cell lines, but also demonstrates an increased inhibitory effect when used in conjunction with BCNU.

Conclusion: The results of this study support the efficacy of S. baicalensis as an anticancer agent for glioblastomas multiforme and a potential adjuvant treatment to current chemotherapeutic agents used in the treatment of both primary and recurrent GBMs. Further studies of the effects of individual flavonoids alone and in combination with each other and with currently used therapies are needed.
\end{abstract}

\section{Background}

Malignant gliomas are one of the more lethal forms of cancer. An estimated 18,000 new cases of brain and central nervous system tumors are diagnosed each year and approximately 13,000 people die of their disease in the United States alone [1]. Those diagnosed with the most malignant form of astrocytoma (glioblastoma multiforme, GBM) have a dismal prognosis. The median survival rate of one year has remained essentially unchanged for a number of years despite aggressive treatment regi- mens that include surgery, radiation and chemotherapy. Complete surgical removal of the tumor is typically not achieved due to the infiltrative nature of these tumors and while radiation and chemotherapy kill the majority of the remaining tumor cells, the rapid recurrence of these tumors suggest the presence within the primary tumor of a subpopulation of cells intrinsically resistant to therapy and capable of survival and growth within the tumor bed following therapy $[2,3]$. When these tumors recur, they are typically refractory to additional courses of the same 
therapies. Improvement in the survival and quality of life of glioma patients requires the design of new therapies or therapeutic combinations that are effective and preferably have fewer side effects than those presently available.

One promising new source of therapeutic agents has been discovered in plant secondary metabolites, irregularly occurring compounds that characterize certain plants or plant groups [4]. Recent interest in these secondary metabolites has been focused upon their medicinal properties [5]. For example, flavonoids are a large group of aromatic plant secondary metabolites that are produced in the plant for the purpose of protection from photosynthetic stress, reactive oxygen species (ROS), wounds and herbivores. Studies of flavonoids have produced the most compelling data for the antitumor activities of plant secondary metabolites in various types of cancers [6], and several flavonoids have been shown to inhibit cancer development while exhibiting antioxidant activities in various animal models [7-11]. Furthermore, some studies suggest that the most promising use of these compounds may be as an adjuvant to currently used therapies $[12,13]$.

Numerous cancer research studies have been conducted using traditional medicinal plants in an effort to discover new therapeutic agents that lack the toxic side effects associated with current chemotherapeutic agents. One of the more versatile plants used as a source of flavonoids is the root of the traditional Chinese medicinal herb Baikal skullcap (Scutellaria baicalensis), a member of the mint family [14]. Traditionally, the dried roots of S. baicalensis were extracted and used in a Chinese herbal medicine "Huang Qin" to treat a variety of ailments [15], and Scutellaria baicalensis has remained an important herb in both Chinese and Japanese traditional prescriptions, such as "Xiao-Chai-Hu-Tang" which is used in the treatment of viral hepatitis and a variety of tumors [16-18]. Various flavonoids isolated from this traditional Chinese medicinal plant were shown to have antiandrogenic and growth inhibitory activity against prostate cancer cells in vitro and in vivo [19-26]. In addition, extracts and isolated flavonoids from this herb have been shown to relieve oxidative stress and immune dysfunction associated with the onset and progress of cancer [8]. Studies have also demonstrated that flavonoids from $S$. baicalensis have the ability to arrest the cell cycle of tumor cell lines that are resistant to multiple chemotherapeutic drugs [27] and act as inhibitors of key steps necessary for the progression of tumor angiogenesis [28].

More recently, Scutellaria baicalensis was used as a component of PCSPES, an herbal mixture that showed efficacy in laboratory trials for prostate cancer, small-cell lung cancer and acute myeloid leukemia [29-34]. Despite these promising results in human trials, this herbal mixture was removed from the market due to concerns about contamination [35]. Subsequent work has shown that flavonoids from $S$. baicalensis were likely to have been at least one of the active ingredients in this herbal mixture [31], and $S$. baicalensis extract and its constituents have been shown to cause reduced expression of the androgen receptor and androgen regulated genes in prostate carcinoma [20]. Recent studies have also shown that the flavonoid-rich extract from the roots of $S$. baicalensis exhibit antiproliferative effects upon prostate, squamous, colon, breast, lung, and liver carcinomas, as well as various leukemia cell lines $[16,21,36,37]$; however, there have been no studies conducted in brain tumors despite suggestions that components of this extract can have effects on microglia in the brain [38]. We, therefore, tested an extract from the root of $S$. baicalensis to determine if it had antiproliferative effects on cells from human malignant brain tumors alone or in combination with 1,3-bis(2-chloroethyl)-1nitrosourea (BCNU, carmustine), an alkylating agent commonly used in the treatment of human brain tumors.

\section{Methods}

\section{Plant material extraction}

Secondary metabolites, including flavonoids and other phenolic compounds, were extracted from ground mature roots of S. baicalensis (common name Huang Qin) using $95 \%$ ethanol. Commercially available roots from a California importer of Chinese herbal medicines (Win Hop Fung, Los Angeles) were obtained and ground into a fine powder using a Scientific Apparatus ${ }^{\mathrm{TM}}$ soil mill. The root powder was stirred for 24 hours in a 95\% ethanol solution in order to extract the secondary metabolites and flavonoids. The crude extract was filtered through a PTFE membrane filter using a Swinney (Millipore Corp., Bedford, $\mathrm{MA}$ ) filtering device. The extract was dried and quantified for the total amount of crude extract. A stock solution was prepared at $25 \mathrm{mg}$ of solid per $\mathrm{ml}$ in absolute ethanol and was further diluted with sterile water immediately before treatment of the cells to achieve a concentration of $10 \mathrm{mg} /$ $\mathrm{ml}$ in a $40 \%(\mathrm{v} / \mathrm{v})$ ethanol solution.

\section{Cell culture}

Cell lines grown from primary and recurrent GBMs from three patients (Table 1) were cultured using previously established protocols [39]. Primary tumors are designated with a 2-letter code (ME, DI) or the last 2 digits of the year followed by a 2-letter code (00WA). The recurrent tumors from the same patient receive the same code with the addition of an "R" (ME/MER, DI/DIR). Following surgery for their primary tumor, both patients from whom we received recurrent tumor samples received 1,3-bis(2-chloroethyl)-1-nitrosourea (BCNU, carmustine) and radiation therapy. Despite therapy, both tumors recurred and the patients underwent additional surgery. Tumor cell line 00WA (Table 1) was selected for use in this study as a low- 
Table I: Patient information

\begin{tabular}{ccccccc}
\hline Tumor code $^{\mathbf{a}}$ & Age $^{\mathbf{b}}$ & Sex & Diagnosisc $^{c}$ & Treatment $^{\mathbf{d}}$ & Days between primary and secondary surgery $^{\text {Survival (days) }}$ \\
\hline DI/DIR & 38 & F & GBM & Irradiation and BCNU & 111 & 426 \\
ME/MER & 49 & F & GBM & Irradiation and BCNU & 138 & 285 \\
OOWA & 39 & M & GBM & NA & NA & NAvf \\
\hline
\end{tabular}

a The tumor code is a random 2 letter code. Recurrent tumor from the same patient receives the same code with the addition of R. For each patient the primary and recurrent tumors were diagnosed by the same neuropathologist.

${ }^{b}$ Age in years at diagnosis of primary tumor.

c GBM = glioblastoma multiforme.

${ }^{d} \mathrm{BCNU}=$ I,3-bis(2-chloroethyl)-I-nitrosourea.

e NA = not applicable since this was a primary tumor.

${ }^{\mathrm{f}} \mathrm{NAv}=$ not available

passage cell line derived from a primary tumor and serial passaged 5 times. Normal glial cells (HJ) grown from a sample obtained from a crainiotomy done for treatment of trauma were also cultured following previously established protocols [39]. All cell lines were cultured in Waymouth's MAB 87/3 (Mediatech, Herndon, Virginia) containing 20\% Fetal Bovine Serum (FBS; Intergen Co., Purchase, NY) and incubated at $37^{\circ} \mathrm{C}$ in a humidified atmosphere of $5 \% \mathrm{CO}_{2}$. To select for the subpopulation of cells resistant to $10 \mu \mathrm{g} / \mathrm{ml} \mathrm{BCNU}$, cells were treated with gradually increasing concentrations of drug as described $[40,41]$. Cells were washed with MAB without serum; they were then mock-treated using $\mathrm{MAB}$ alone or treated with increasing concentrations of $\mathrm{BCNU}$ in $\mathrm{MAB}(2.5,5.0,7.5$, $10 \mu \mathrm{g} / \mathrm{ml}$ ) for 1 hour at $37^{\circ} \mathrm{C}$ with $5 \% \mathrm{CO}_{2}$. Cells were subsequently washed and fed with $\mathrm{MAB}$ containing $20 \%$ FBS. The cells were treated for three consecutive days then allowed to grow. Treatment was repeated several times until the cells in culture were resistant to $10 \mu \mathrm{g} / \mathrm{ml}$ of BCNU (ME Drug/MER Drug and DI Drug/DIR Drug) as evidenced by the absence of cell death compared to that observed in the mock-treated cultures. Cells were retreated with $10 \mu \mathrm{g} / \mathrm{ml}$ BCNU every 8-10 passages to maintain the resistant phenotype.

\section{AlamarBlue ${ }^{\mathrm{TM}}$ metabolic assay}

Cells were seeded at a density of approximately $1-4 \times 10^{3}$ cells in $200 \mu \mathrm{l}$ per well. Following a 24-hour incubation period, cells were treated with $100 \mu \mathrm{g} / \mathrm{ml}$ of $S$. baicalensis extract containing $0.4 \%$ ethanol (v/v) in $200 \mu \mathrm{l}$ of medium. Mock treatment consisted of a $0.4 \%(\mathrm{v} / \mathrm{v})$ solution of ethanol in $200 \mu \mathrm{l}$ of medium. Cellular metabolic activity was assayed using AlamarBlue ${ }^{\mathrm{TM}}$ (Serotec, Raleigh, NC) and the manufacturer's protocol at 0, 1, 3, 7, 10, and 15 days following treatment. The fluorescent reading was performed using a microtiter plate reader $(485 \mathrm{~nm} \lambda$ excitation, $595 \lambda$ nm emission).

\section{Colony forming assay}

A Colony Forming Assay (CFA) was used to verify that the cells remaining metabolically active following treatment with $S$. baicalensis extract were also capable of prolifera- tion. Cells were diluted and divided into aliquots containing approximately $1.5 \times 10^{3}$ cells. Aliquots were treated with a single dose of 0 (untreated), 10, 25, 50, 75, 100, 150 and $200 \mu \mathrm{g} / \mathrm{ml}$ of the extract in MAB $87 / 3$ medium supplemented with $20 \%$ FBS for 1 hour. Following incubation, cells were washed three times with fresh medium. Cells were resuspended in the medium and aliquots of 1.5 ml containing approximately $2 \times 10^{3}$ cells were dispensed into three $60 \mathrm{~mm}$ culture dishes. Cells were cultured for at least 6 divisions, approximately 14 days, before they were fixed with methanol and stained with $4 \%$ Giemsa stain. Colonies, defined as 50 or more cells, were counted and plotted as a percentage of the control (untreated) colonies.

\section{Trypan blue exclusion cell viability assay}

The cells were plated at approximately $1 \times 10^{5}$ cells per well in 6-well tissue culture plates in $2 \mathrm{ml}$ of medium and incubated at $37^{\circ} \mathrm{C}$ at $5 \% \mathrm{CO}_{2}$. After 24 hours, the medium was removed and replaced with fresh medium plus 20\% FBS and supplemented with $S$. baicalensis extract $(0,25,50,100,150$, and $200 \mu \mathrm{g} / \mathrm{ml})$ or a combination of S. baicalensis extract and BCNU $(2.5$ or $5 \mu \mathrm{g} / \mathrm{ml})$. Cells were harvested 48 hours after treatment by digestion with $0.25 \%$ trypsin-EDTA solution at $37^{\circ} \mathrm{C}$ for $2-3$ minutes. The cells were stained with trypan blue and live cells were enumerated. Cell counts were expressed as mean \pm standard deviation (SD).

\section{Statistical analysis}

All results are expressed as mean \pm standard deviation (SD). Statistical differences between correlated samples were evaluated using Student's $t$-test and noted to be significantly different where $\mathrm{p}<0.05$. Student $t$-test calculations were assessed on the VassarStats Statistical Computation website [42]. Composite treatments were compared using one-way analysis of variances (ANOVA) and considered significantly different where probability values were found to be equal to or less than 0.05. All ANOVA tests, as well as mean and SD calculations, were performed using GraphPad Prism (GraphPad Software, Inc., San Diego, USA). 


\section{Results}

Effects of S. baicalensis on glioma cell metabolic activity The metabolic inhibitory effects of an extract from S. baicalensis were studied in cell lines cultured from paired primary (ME) and recurrent (MER) glioblastoma multiforme (GBM) tumors obtained from a single patient, as well as primary and recurrent cells that have been selected in vitro for resistance to $10 \mu \mathrm{g} / \mathrm{ml}$ of BCNU (ME Drug/MER Drug). Metabolic activity was assessed at 0, 1, 3, 7, 10, and 15 days following treatment with $100 \mu \mathrm{g} / \mathrm{ml}$ of the extract using an AlamarBlue metabolic assay. All wells were subconfluent when the experiment was begun to allow for changes in cell growth. In this way, we would see a difference regardless of whether the effect of the extract was cytotoxic or cytostatic. There was a significant $(\mathrm{p}<.05 ; \mathrm{n}$ $=5$ ) difference in the metabolic activity exhibited by cells treated with S. baicalensis extract compared with mock- or ethanol treated cells. There was no increase in metabolic activity exhibited in the ME and MER glioma cell lines, as well as subpopulations of these cell lines that were selected for BCNU resistance (ME Drug and MER Drug) for the 15 day duration of the experiment (Figure 1), while the untreated glioma cells (controls) exhibited exponential increases in metabolic activity. As an additional control, glioma cells were treated with a $0.4 \%(\mathrm{v} / \mathrm{v})$ ethanol solution (solvent vehicle). Although there was some difference in fluorescence between untreated and ethanol treated MER cells at day 7 (Figure 1D) and 10 (Figure 1C), there was good growth in all four cell lines and the ethanol-treated cells showed no significant decrease in metabolic activity compared to the untreated control cells by the fifteenth day of culture. Microscopic

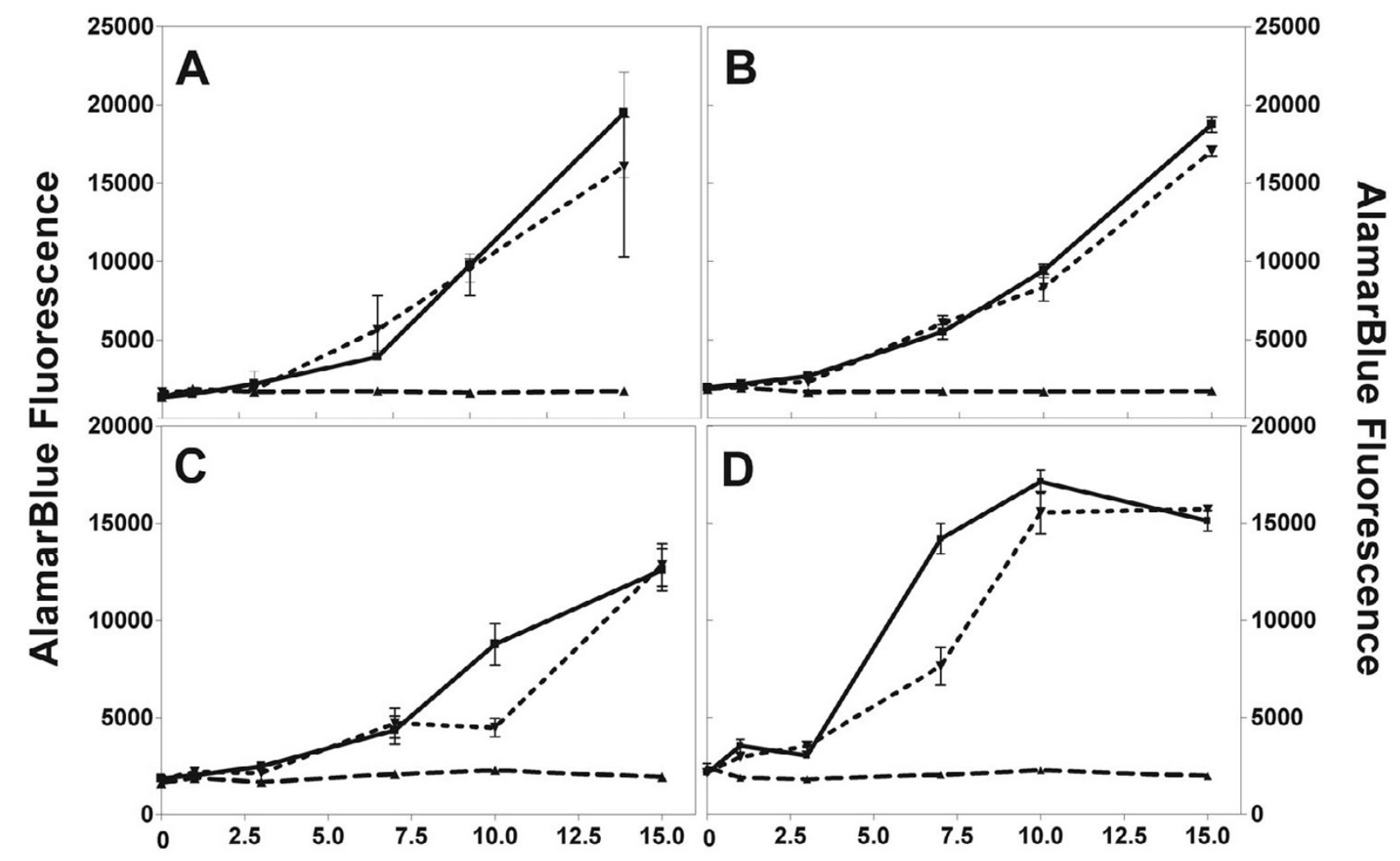

\section{Days}

\section{Figure I}

Time course treatment of ME series cells with S. baicalensis extract. Metabolic activity was measured using AlamarBlue ${ }^{\mathrm{TM}}$. Wells were subconfluent on Day 0 . Cells were left untreated $(\square-\square)$, mock treated with $0.4 \%$ ethanol $(\nabla-\nabla)$ or treated with a $0.4 \%$ ethanol solution containing $100 \mu \mathrm{g} / \mathrm{ml} \mathrm{S}$. baicalensis extract $(\triangle-\triangle)$. Data is mean \pm SD using 5 replicates. (A) cells from primary tumor (ME), (B) ME cells selected for resistance to $10 \mu \mathrm{g} / \mathrm{ml} \mathrm{BCNU} \mathrm{(ME} \mathrm{drug),} \mathrm{(C)} \mathrm{cells} \mathrm{from} \mathrm{recurrent} \mathrm{tumor} \mathrm{(MER),}$ (D) cells from recurrent tumor selected for resistance to $10 \mu \mathrm{g} / \mathrm{ml} \mathrm{BCNU}$ (MER drug). 
examination showed extensive cytopathic effect (CPE) in cells treated with the $S$. baicalensis extract (data not shown).

\section{Effects of S. baicalensis on glioma cell viability and proliferation}

Colony forming assays were done to demonstrate a dose response to the $S$. baicalensis extract and to show that the effect is cytopathic and not cytostatic. Cells from the paired primary and recurrent tumors ME/MER and DI/ DIR prior to and following selection for resistance to 10 $\mu \mathrm{g} / \mathrm{ml} \mathrm{BCNU}$ were treated with $0-200 \mu \mathrm{g} / \mathrm{ml}$ S. baicalensis extract as described in the methods section. Cells were allowed to grow to form colonies of at least 50 cells. As seen in Figure 2, cells from all 8 cell lines showed a dosedependent response to the $S$. baicalensis extract.

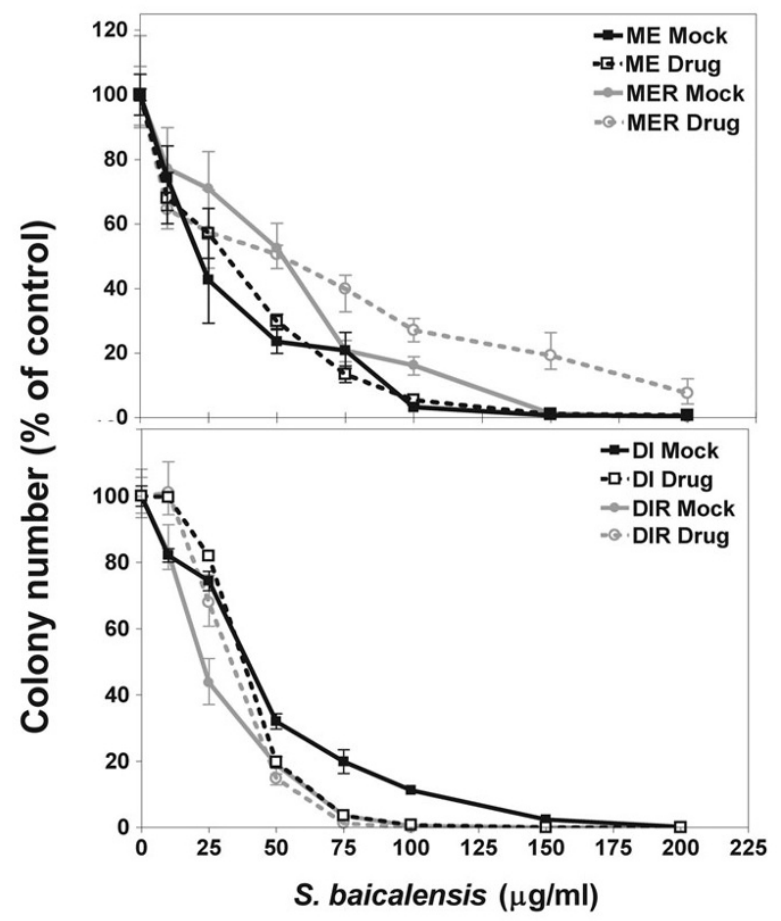

Figure 2

Dose-dependent inhibition of glioma cell proliferation by Scutellaria baicalensis extract. Glioma cell lines from primary tumors (ME and DI) and recurrent (MER and DIR) tumors, as well as BCNU resistant (designated "Drug") glioma cell lines were cultured with various concentrations of $S$. baicalensis extract $(0-200 \mu \mathrm{g} / \mathrm{ml})$. After treatment, cells were incubated for 14 days to allow for colony growth. Colonies of at least 50 cells were counted using a $4 \%$ Giemsa stain. Results were normalized to the control (untreated cells). Data show means \pm SD of 3 replicates.
To demonstrate that the effect of the $S$. baicalensis extract on glioma cells was not a result of long-term in vitro cultivation of the cells, we tested the extract on cell line 00WA after 5 serial passages in vitro. This was the minimum number of passages required to obtain enough cells to perform the assay. Cells were treated with varying concentrations of the $S$. baicalensis extract as described in the Methods section, and the percentage of viable cells was determined by trypan blue exclusion 48 hours later. Figure 3 shows that the extract caused a dose-dependent reduction in viability similar to that observed in the $\mathrm{ME} /$ MER and DI/DIR cell line series.

\section{Effects of S. baicalensis on normal glial cells}

To assess whether the extract demonstrates toxicity in normal cells, normal human glial cells (HJ) were plated and allowed to grow until they were close to confluence. These cells were then cultured in the presence and absence of various concentrations of the extract for 48 hours. As shown in Figure 4, normal glial cells treated with 25-100 $\mu \mathrm{g} / \mathrm{ml}$ of $S$. baicalensis extract for 48 hours displayed no significant change $(\mathrm{p}>.05 ; \mathrm{n}=3)$ in metabolic activity assayed using AlamarBlue and compared to the control (untreated) cells. For comparison, a recurrent glioma cell line (MER) was also treated with $25-100 \mu \mathrm{g} / \mathrm{ml}$ of the extract for 48 hours. The glioma cells treated with $S$. baicalensis extract at concentrations of 50 and $100 \mu \mathrm{g} / \mathrm{ml}$ displayed a significant reduction $(\mathrm{p}<.05, \mathrm{n}=3)$ in metabolic activity when compared to the metabolic activity of the control (untreated) cells.

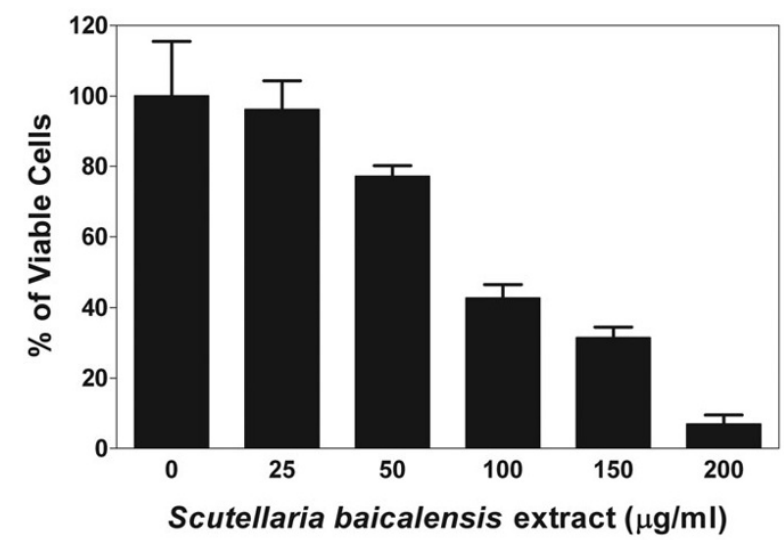

Figure 3

Dose-dependent growth inhibition of a low-passage glioma cell line by an extract from $S$. baicalensis. The viability of cell line 00WA following treatment with $0-200 \mu \mathrm{g} / \mathrm{ml}$ of S. baicalensis extract was tested by trypan blue exclusion at serial passage 5 . Results are the mean \pm SD of 2 replicates and data were normalized to the control. 
A

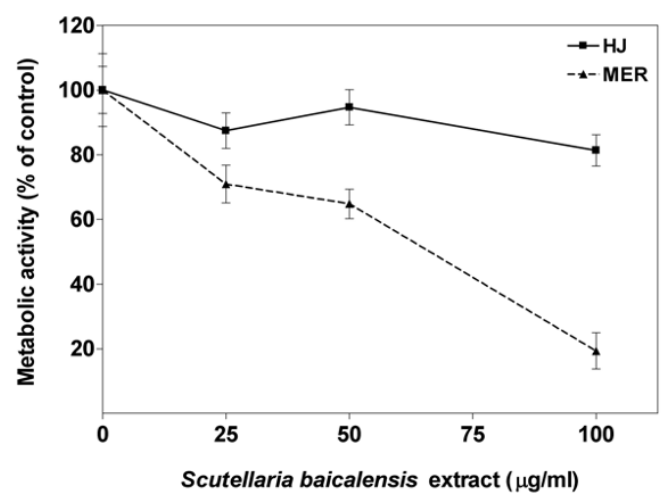

B

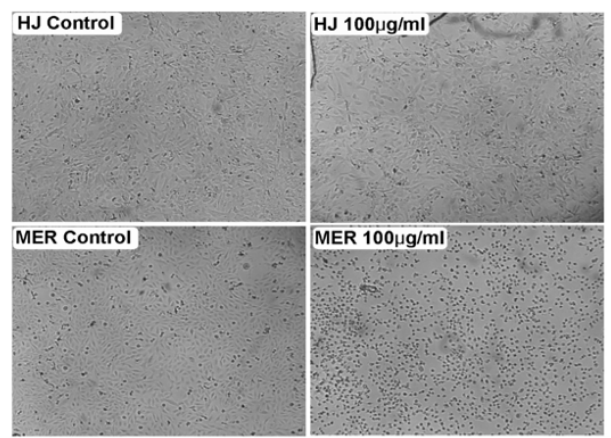

\section{Figure 4}

The cytotoxic effects of Scutellaria baicalensis extract on normal glial cells and glioma cells. Wells were essentially confluent at the beginning of the experiment. (A) Metabolic activity of normal glial cells $(\mathrm{HJ})$ and cells from a recurrent tumor (MER) were measured using the AlamarBlue ${ }^{\mathrm{TM}}$ metabolic assay. Glioma cells were cultured with $100 \mu \mathrm{g} / \mathrm{ml}$ of the $S$. baicalensis extract for approximately 48 hours. Results were presented as a percentage of the control (untreated). Data show means \pm SD of 3 replicates. (B) Photomicrographs of cells 48 hours following treatment with $100 \mu \mathrm{g} / \mathrm{ml}$ of S. baicalensis extract.

Microscopic examination of the cells following treatment with $100 \mu \mathrm{g} / \mathrm{ml}$ of the extract showed marked differences in the normal glial cells compared to the tumor cells (Figure $4 \mathrm{~B}$ ). The MER culture demonstrated an increase in the number of detached cells floating in the medium. The floating cells exhibited atypical morphologies such as DNA condensation, a hallmark of cell death (Figure 4B). The normal glial $(\mathrm{HJ})$ cells did not show a substantial increase in floating cells or cells with DNA condensation or other hallmarks of cell death.

\section{Combination treatment with S. baicalensis and BCNU}

To determine if the $S$. baicalensis extract could potentiate the effects of conventional chemotherapeutic agents, we tested the effect of combined treatment using $50 \mu \mathrm{g} / \mathrm{ml}$ of S. baicalensis extract and $2.5 \mu \mathrm{g} / \mathrm{ml}$ of BCNU on the viabil- ity of cells from primary and recurrent cells selected for resistance to $10 \mu \mathrm{g} / \mathrm{ml} \mathrm{BCNU}$ (Figure $5 \mathrm{~A}$ ). As expected, 2.5 $\mu \mathrm{g} / \mathrm{ml}$ of BCNU alone had no effect on these cells and 50 $\mu \mathrm{g} / \mathrm{ml}$ of $S$. baicalensis extract reduced viability to $15-30 \%$ of control; however, when used in combination survival was reduced substantially, particularly in the DI and DIR cell lines. The differences between the individual treatments and the combined treatment were found to be significant in all but the ME drug cells by one-way ANOVA (ME Drug: $\mathrm{P}=0.0557 \mathrm{~F}=8.785$; MER Drug: $\mathrm{P}=0.0116 \mathrm{~F}$ $=27.77$; DI Drug: $\mathrm{P}=0.0005 \mathrm{~F}=253.3$ and DIR Drug: $\mathrm{P}=$ $0.0010 \mathrm{~F}=144.1$ ). Fewer than $5 \%$ of any of the cells survived when the BCNU dose was increased to $5 \mu \mathrm{g} / \mathrm{ml}$, even though this dose alone caused little, if any, CPE (data not shown). Microscopic examination of the combined

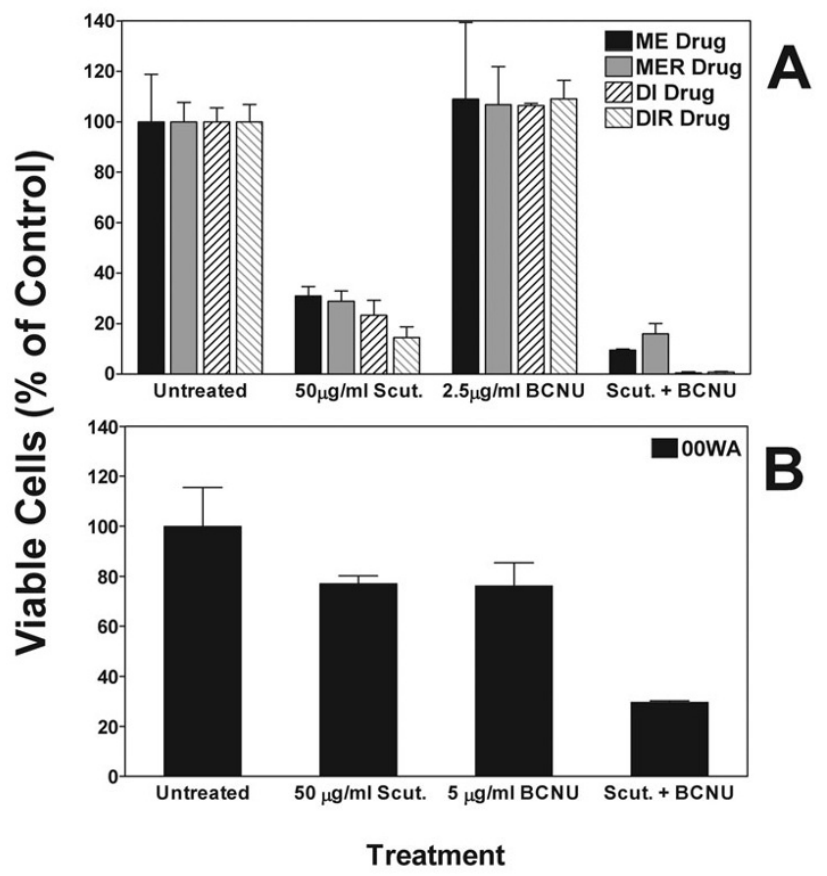

\section{Figure 5}

The effects of Scutellaria baicalensis extract $(50 \mu \mathrm{g} / \mathrm{ml})$ and $\mathrm{BCNU}$ on glioma cell viability in BCNU-resistant and low passage cell lines. (A) Glioma cell lines from primary and recurrent tumors (ME/MER; DI/DIR) selected for resistance to $10 \mu \mathrm{g} / \mathrm{ml} \mathrm{BCNU}$ (designated "Drug") were treated with either $50 \mu \mathrm{g} / \mathrm{ml}$ of S. baicalensis extract alone (Scut.), $2.5 \mu \mathrm{g} /$ $\mathrm{ml}$ of $\mathrm{BCNU}$ alone, or a combination of the $S$. baicalensis extract and BCNU (Scut. + BCNU). (B) Low passage cells from tumor 00WA were treated with either $50 \mu \mathrm{g} / \mathrm{ml}$ of $S$. baicalensis extract alone (Scut.), $5 \mu \mathrm{g} / \mathrm{ml}$ of BCNU alone, or a combination of the $S$. baicalensis extract and BCNU (Scut. + $\mathrm{BCNU})$. The percentage of viable cells following 3 consecutive days of treatment was assessed using a trypan blue exclusion assay. Results are normalized to the control (untreated) cells and data is the mean \pm SD for 2 replicates. 
effects of BCNU and the S. baicalensis extract again indicated an increase in the number of detached (floating) cells with atypical morphologies when compared to cells treated with either BCNU or the extract alone (Figure 6).

The effect of combined treatment on low passage, BCNU naive 00WA cells showed a similar significant potentiation of the drug effect, although the overall effect was less than that observed with the ME and DI cell series (Figure 5B). BCNU or S. baicalensis extract alone reduced viability to $75 \%$; however, combination treatment resulted in a reduction of viability to $30 \%$ of the control, mock-treated cells ( $\mathrm{p}=0.0141 \mathrm{~F}=24.20$ by one-way ANOVA).

\section{Discussion}

Treatment of malignant brain tumors typically includes surgery, radiation and chemotherapy; however, this tumor typically recurs following therapy and the recurrent tumor is often refractory to additional therapy. The identification of a novel therapy that is effective against recurrent tumor could substantially impact the morbidity and median survival of patients with this disease. The purpose of this study was to investigate the effects of plant secondary metabolites from Scutellaria baicalensis on cells from primary and recurrent gliomas prior to, and following, selection for therapy resistance.

There are many reports of the medicinal utility of the Chinese herb $S$. baicalensis for the treatment of a host of diseases. Although there have been numerous studies on the
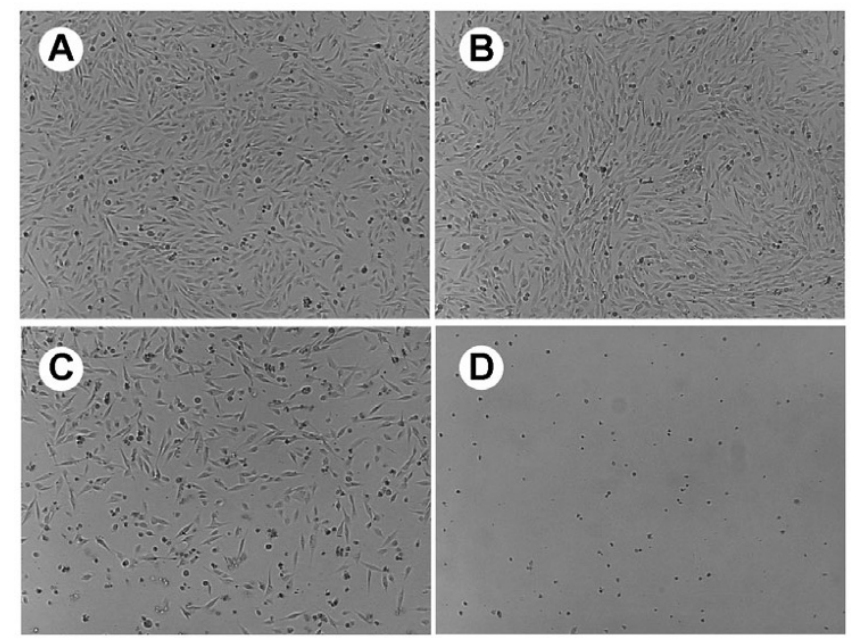

\section{Figure 6}

Photomicrographs of ME Drug cells (selected for resistance

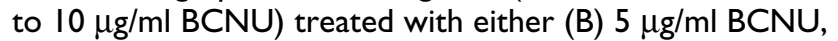

(C) $50 \mu \mathrm{g} / \mathrm{ml}$ of $S$. baicalensis extract, (D) or a combination of S. baicalensis extract and BCNU. Glioma cells were treated for 3 consecutive days and then compared to the $(A)$ control (untreated) cells. effects of S. baicalensis extracts and isolated flavonoids on cancer cells, few have studied their effects on glioma cells. Further, there are no studies examining the effect of extracts of this herb on cells from tumors that have recurred following standard therapies. We, therefore, tested an ethanol extract from $S$. baicalensis for its ability to inhibit the growth of cells from primary gliomas, cells from recurrent gliomas from the same patient and cells selected for resistance to BCNU therapy in vitro. We also tested cells cultured from primary gliomas after only 5 serial passages in vitro. Our work demonstrated that the $S$. baicalensis extract caused a dose-dependent inhibition of growth of all of these cell lines, irrespective of whether they were from a primary or recurrent tumor. Reduced metabolic activity due to the $S$. baicalensis extract was demonstrated using AlamarBlue ${ }^{\mathrm{TM}}$, and cytotoxicity was demonstrated by colony forming assays as well as by trypan blue exclusion and microscopic examination. A dose of $50 \mu \mathrm{g} / \mathrm{ml}$ of the extract typically reduced the population of glioma cells by at least $50 \%$ of the control (untreated) population; however, the same dose of extract had little, if any, effect on HJ cells, the cultured normal glia. In fact, $25-100 \mu \mathrm{g} / \mathrm{ml}$ of $S$. baicalensis extract did not induce the same inhibitory effects in HJ cells that were observed in all of the glioma cells tested. The normal glial cells also failed to undergo the typical morphological changes seen following treatment of the glioma cells. This suggests that the $S$. baicalensis extract may not affect normal cells to the extent that it affects tumor cells, thus warranting in vivo studies.

The effect of the $S$. baicalensis extract on cells from recurrent tumor is of particular interest. Recurrent tumor generally arises from cells in the primary tumor that survived treatment with radiation and chemotherapy; thus, recurrent tumor is often refractile to further therapies. Our data demonstrates that not only are the cells from recurrent tumor sensitive to the effects of the S. baicalensis extract, but cells from primary and recurrent tumor selected for resistance to $10 \mu \mathrm{g} / \mathrm{ml} \mathrm{BCNU}$ are sensitive to lower doses when given in combination with $S$. baicalensis extract. This suggests that this extract may have its greatest utility when used in combination with currently available therapies. This work is similar to previous studies showing that $S$. baicalensis extracts may reduce tumor growth and proliferation when applied to chemotherapy and radiation resistant tumors in various forms of cancer [18,43-45]. One postulated mechanism for this is the inhibition of extracellular signal-regulated kinase (ERK). Pathways involving ERK are activated in most GBMs [46], and inhibition of ERK has been shown to inhibit growth of GBMs and medulloblastomas alone and in combination with temozolomide $[47,48]$. 
The effects of extracts and isolated flavonoids are not all antiproliferative. Choi et al [49] found that an aqueous extract from $S$. baicalensis reduced the apoptotic death induced in neuronal HT-22 cells exposed to $\mathrm{H}_{2} \mathrm{O}_{2}$ by increased Bcl-2 and reducing Bax levels. In addition, baicalein, a major component of the S. baicalensis extract, can exert either pro- or anti-apoptotic activity depending on the cell type. For example, in addition to its antiproliferative effects, baicalein has been shown to prevent the loss of viability and apoptosis induced in the human glioma cell line A172 by cisplatin [50]. Regardless of this, our data has demonstrated a potential role for the use of $S$. baicalensis as an adjuvant therapy in the treatment of human malignant brain tumors, particularly recurrent tumors.

\section{Conclusion}

In summary, the results of this study support the efficacy of $S$. baicalensis as an anticancer agent for glioblastomas multiforme and a potential adjuvant treatment to current chemotherapeutic agents used in the treatment of both primary and recurrent GBMs. Further studies of the effects of individual flavonoids alone and in combination with each other and with currently used therapies are in progress.

\author{
Abbreviations \\ tine) \\ glioblastoma multiforme (GBM) \\ Scutellaria baicalensis (S. baicalensis) \\ colony forming assay (CFA) \\ cytopathic effect (CPE)
}

1,3-bis(2-chloroethyl)-1-nitrosourea (BCNU， carmus-

\section{Competing interests}

The author(s) declare that they have no competing interests.

\section{Authors' contributions}

This work was done in partial fulfillment of the requirements for a Master's Degree by KP. ACS and WDC conceived the study and directed its design and coordination. WDC provided the materials for the $S$. baicalensis extract and directed its preparation. ACS and $\mathrm{NCH}$ provided the glioma cells and directed their use and chemotherapy resistance testing. KP did the cell culture and all resistance assays. All authors read the manuscript and agreed to its contents.

\section{Acknowledgements}

We thank William P. Hendricks, Claudia Chavez and Judson L. Kilbourn for technical assistance and Jeanette K. Pueschel for helpful discussions. We also thank the neurosurgeons and operating room staff of the Barrow Neurological Institute and Memorial Hospital for providing the samples used to establish the cell lines utilized in this work. We are also grateful for the editorial assistance of Kathleen Furlong. This work was supported by the Barrow Neurological Foundation, a Graduate and Professional Student Association Graduate Research Grant from Arizona State University and the College of Liberal Arts and Sciences, Arizona State University.

\section{References}

I. American Cancer Society: Cancer Facts and Figures 2006. Atlanta, American Cancer Society; 2006.

2. Mousseau M, Chauvin C, Nissou MF, Chaffanet M, Plantaz D, Pasquier $B$, Schaerer R, Benabid A: A study of the expression of four chemoresistance-related genes in human primary and metastatic brain tumours. Eur J Cancer 1993, 29A:753-759.

3. Scheck AC, Shapiro JR, Coons SW, Norman SA, Johnson PC: Biological and molecular analysis of a low grade recurrence of a glioblastoma multiforme. Clin Cancer Res 1996, 2:187-199.

4. Seigler DS: Plant Secondary Metabolism Boston: Kluwer Academic; 1998.

5. Harborne JB: Arsenal for survival: secondary plant products. Taxon 2000, 49:435-449.

6. Yang CS, Landau JM, Huang MT, Newmark HL: Inhibition of carcinogenesis by dietary polyphenolic compounds. Ann Rev Nutr 200I, $21: 381-406$.

7. Kuo SM: Dietary flavonoid and cancer prevention: evidence and potential mechanism. Crit rev Oncogenesis 1997, 8:47-69.

8. Lahiri-Chatterjee M, Katiyar SK, Mohan RR, Agarwal R: A flavonoid antioxidant, silymarin, affords exceptionally high protection against tumor promotion in the SENCAR mouse skin tumorigenesis model. Cancer Res 1999, 59:622-632.

9. Ingram D, Sanders K, Kolybaba M, Lopez D: Case control study of phyto-oestrogens and breast cancer. Lancet 1997, 350:990-994.

10. Messina MJ, Persky V, Setchell KDR, Barnes S: Soy intake and cancer risk: a review of the in vitro and in vivo data. Nutr Cancer 1994, $21:$ I|3-13|.

II. Barnes S, Peterson TG, Coward L: Rationale for the use of genistein-containing soy matrices in chemoprevention trials for breast and prostate cancer. / Cell Biochem 1995, 22S: 181-187.

12. Khoshyomn S, Manske GC, Lew SM, Wald SL, Penar PL: Synergistic action of genistein and cisplatin on growth inhibition and cytotoxicity of human medulloblastoma cells. Pediatr Neurosurg 2000, 33: $123-13 \mid$

13. Khoshyomn S, Nathan D, Manske GC, Osler TM, Penar PL: Synergistic effect of genistein and BCNU on growth inhibition and cytotoxicity of glioblastoma cells. J Neurooncol 2002, 57:193-200.

14. Chung CP, Park JB, Bae KH: Pharmocological effects of methanolic extract from the root of Scutellaria baicalensis and its flavonoids on human gingival fibroblast. Planta Med 1995, 61:150-153.

15. Maloney D: The American Association of Oriental Medicine's Complete Guide to Chinese Herbal Medicine. New York: The Berkley Publishing Group; 1998.

16. Fei $Y, X u i ~ L, Y i j$, Zhang W, Zhang DY: Anticancer activity of Scutellaria baicalensis and its potential mechanism. J Altern Complement Med 2002, 8:567-572.

17. Tajiri H, Kozaiwa K, Ozaki Y, Miki K, Shimuzu K, Okada S: Effect of sho-saiko-to (xiao-chai-hu-tang) on $\mathrm{HBeAg}$ clearance in children with chronic hepatitis $B$ virus infection with sustained liver disease. Am J Chin Med I991, 19:121-129.

18. Yano H, Mizoguchi A, Fukuda K, Haramaki M, Ogasawara S, Momosaki S, Kojiro M: The herbal medicine sho-saiko-to inhibitsproliferation of cancer cell lines by inducing apoptosis and arrest at the $\mathbf{G}_{0} / \mathbf{G}_{\mathbf{I}}$ phase. Cancer Res 1994, 54:448-454.

19. Bigler D, Gulding KM, Dann R, Sheabar FZ, Conaway MR, Theodorescu D: Gene profiling and promoter reporter assays: novel tools for comparing the biological effects of botanical extracts on human prostate cancer cells and understanding their mechanisms of action. Oncogene 2003, 22: I 26I-I 272.

20. Bonham M, Posakony J, Coleman I, Montgomery B, Simon J, Nelson PS: Characterization of chemical constituents in Scutellaria baicalensis with antiandrogenic and growth-inhibitory activ- 
ities toward prostate carcinoma. Clin Cancer Res 2005, II:3905-39|4

21. Chan FL, Choi HL, Chen ZY, Chan PS, Huang Y: Induction of apoptosis in prostate cancer cell lines by a flavonoid, baicalin. Cancer Lett 2000, 160:219-228.

22. Chen S, Ruan Q, Bedner E, Deptala A, Wang X, Hsieh TC, Traganos F, Darzynkiewicz Z: Effects of the flavonoid baicalin and its metabolite baicalein on androgen receptor expression, cell cycle progression and apoptosis of prostate cancer cell lines. Cell Prolif 200I, 34:293-304.

23. Ikezoe T, Chen SS, Yang Y, Heber D, Taguchi H, Koeffler HP: PCSPES: Molecular mechanism to induce apoptosis and downregulate expression of PSA in LNCaP human prostate cancer cells. Int J Oncol 2003, 23: | 46 |- | 470.

24. Kobayashi T, Nakata T, Kuzumaki T: Effect of flavonoids on cell cycle progression in prostate cancer cells. Cancer Lett 2002, 176:17-23.

25. Lu X, Guo J, Hsieh TC: PC-SPES inhibits cell proliferation by modulating P2I, cyclins D, E and B and multiple cell cyclerelated genes in prostate cancer cells. Cell Cycle 2003, 2:59-63.

26. Sadava D, Winesburg J: Contaminants of PC-SPES are not responsible for cytotoxicity in human small-cell lung carcinoma cells. Cancer Lett 2005, 220:17|-I75.

27. Choi SU, Ryu SY, Yoon SK, Jung NP, Park SH, Kim KH, Choi EJ, Lee $\mathrm{CO}$ : Effects of flavonoids on the growth and cell cycle of cancer cells. Anticancer Res 1999, 19:5229-5233.

28. Liu JJ, Huang TS, Cheng WF, Lu FJ: Baicalein and baicalin are potent inhibitors of angiogenesis: Inhibition of endothelial cell proliferation, migration and differentiation. Int J Cancer 2003, I 06:559-565.

29. Chung VQ, Tattersall M, Cheung HT: Interactions of a herba combination that inhibits growth of prostate cancer cells. Cancer Chemother Pharmacol 2004, 53:384-390.

30. Cordell GA: PC-SPES: a brief overview. Integr Cancer Ther 2002 I:27I-286

31. Hsieh TC, Lu X, Chea J, Wu JM: Prevention and management of prostate cancer using PC-SPES: a scientific perspective. J Nutr 2002, 132:3513S-3517S.

32. Ikezoe T, Chen S, Saito T, Asou H, Kyo T, Tanosaki S, Heber D Taguchi H, Koeffler HP: PC-SPES decreases proliferation and induces differentiation and apoptosis of human acute myeloid leukemia cells. Int J Oncol 2003, 23:1203-121I.

33. Meyer JP, Gillatt DA: PC-SPES: a herbal therapy for the treatment of hormone refractory prostate cancer. Prostate Cancer Prostatic Dis 2002, 5:13-15.

34. Oh WK, Kantoff PW, Weinberg V, Jones G, Rini BI, Derynck MK, Bok R, Smith MR, Bubley G], Rosen RT, DiPaola RS, Small EJ: Prospective, multicenter, randomized phase II trial of the herbal supplement, PC-SPES, and diethylstilbestrol in patients with androgen-independent prostate cancer. J Clin Oncol 2004, 22:3705-37I2

35. Richardson MA, Straus SE: Complementary and Alternative Medicine: Opportunities and Challenges for Cancer Management and Research. Sem Onc 2002, 29:531-545.

36. Huang HC, Hsieh LM, Chen HW, Lin YS, Chen JS: Effects of baicalein and esculetin on transduction signals and growth factors expression in T-lymphoid leukemia cells. Eur J Pharmacol 1994, 268:73-78.

37. Motoo Y, Sawabu N: Antitumor effects of saikosaponins, baicalin and baicalein on human hepatoma cell lines. Cancer Lett 1994, 86:91-95.

38. Suk K, Lee H, Kang SS, Cho G], Choi WS: Flavonoid baicalein attenuates activation-induced cell death of brain microglia. J Pharmacol Exp Ther 2003, 305:638-645.

39. Asch AS, Leung LLK, Shapiro JR, Nachman RL: Human brain glial cells synthesize thrombospondin. Proc Natl Acad Sci USA 1986 83:2904-2908

40. Scheck AC, Mehta BM, Beikman MK, Shapiro JR: BCNU-resistant human glioma cells with over-representation of chromosomes 7 and 22 demonstrate increased copy number and expression of platelet-derived growth factor genes. Genes, Chromosomes \& Cancer 1993, 8: I37-I48.

4I. Shapiro JR, Pu P-Y, Mohamed AN, Galicich JH, Ebrahim SAD, Shapiro WR: Chromosome number and carmustine sensitivity in human gliomas. Cancer 1993, 71:4007-4021.
42. VassarStats Statistical Computation website 2006 [http://fac ulty.vassar.edu/lowry/VassarStats.html]

43. Lee MJ, Wang CJ, Tsai YY, Hwang JM, Lin WL, Tseng TH, Chu CY: Inhibitory effect of 12-O-tetradecanoylphorbol-13-acetatecaused tumor promotion in benzo[a]pyrene-initiated CD-I mouse skin by baicalein. Nutr Cancer 1999, 34:185-191.

44. Aung HH, Dey L, Mehendale S, Xie JT, Wu JA, Yuan CS: Scutellaria baicalensis extract decreases cisplatin-induced pica in rats. Cancer Chemother Pharmacol 2003, 52:453-458.

45. Cipak L, Rauko P, Miadokova E, Cipakova I, Novotny L: Effects of flavonoids on cisplatin-induced apoptosis of HL-60 and LI 210 leukemia cells. Leuk Res 2003, 27:65-72.

46. Bhaskara VK, Panigrahi M, Challa S, Babu PP: Comparative status of activated ERKI/2 and PARP cleavage in human gliomas. Neuropathology 2005, 25:48-53.

47. Momota $\mathrm{H}$, Nerio E, Holland EC: Perifosine inhibits multiple signaling pathways in glial progenitors and cooperates with temozolomide to arrest cell proliferation in gliomas in vivo. Cancer Res 2005, 65:7429-7435.

48. Sturla LM, Cowan CW, Guenther L, Castellino RC, Kim JY, Pomeroy SL: A novel role for extracellular signal-regulated kinase 5 and myocyte enhancer factor 2 in medulloblastoma cell death. Cancer Res 2005, 65:5683-5689.

49. Choi J, Conrad CC, Malakowsky CA, Talent JM, Yuan CS, Gracy RW: Flavones from Scutellaria baicalensis Georgi attenuate apoptosis and protein oxidation in neuronal cell lines. Biochim Biophys Acta 2002, I 57 I:201-2 I0.

50. Lee SW, Song GS, Kwon CH, Kim YK: Beneficial effect of flavonoid baicalein in cisplatin-induced cell death of human glioma cells. Neurosci Lett 2005, 382:7I-75.

\section{Pre-publication history}

The pre-publication history for this paper can be accessed here:

http://www.biomedcentral.com/1472-6882/6/27/prepub

Publish with BioMed Central and every scientist can read your work free of charge

"BioMed Central will be the most significant development for disseminating the results of biomedical research in our lifetime. "

Sir Paul Nurse, Cancer Research UK

Your research papers will be:

- available free of charge to the entire biomedical community

- peer reviewed and published immediately upon acceptance

- cited in PubMed and archived on PubMed Central

- yours - you keep the copyright 